Grand Valley State University

ScholarWorks@GVSU

$5-2004$

\title{
Acetylcholine Protection of Adult Pig Retinal Ganglion Cells from Glutamate-Induced Excitotoxicity
}

\author{
Erica Wehrwein \\ Western Michigan University \\ Sean A. Thompson \\ Western Michigan University \\ Sylvie F. Coulibaly \\ Western Michigan University \\ David M. Linn \\ Grand Valley State University, linnd@gvsu.edu \\ Cindy L. Linn \\ Western Michigan University
}

Follow this and additional works at: https://scholarworks.gvsu.edu/bms_articles

Part of the Animal Structures Commons, and the Sense Organs Commons

\section{ScholarWorks Citation}

Wehrwein, Erica; Thompson, Sean A.; Coulibaly, Sylvie F.; Linn, David M.; and Linn, Cindy L., "Acetylcholine Protection of Adult Pig Retinal Ganglion Cells from Glutamate-Induced Excitotoxicity" (2004). Peer Reviewed Articles. 32.

https://scholarworks.gvsu.edu/bms_articles/32

This Article is brought to you for free and open access by the Biomedical Sciences Department at ScholarWorks@GVSU. It has been accepted for inclusion in Peer Reviewed Articles by an authorized administrator of ScholarWorks@GVSU.For more information, please contact scholarworks@gvsu.edu. 


\title{
Acetylcholine Protection of Adult Pig Retinal Ganglion Cells from Glutamate-Induced Excitotoxicity
}

\author{
Erica Webrwein, Sean A. Thompson, Sylvie F. Coulibaly, David M. Linn, and Cindy L. Linn
}

Purpose. To determine which glutamate receptor (GluR) subtypes are responsible for glutamate-induced excitotoxicity in cultured adult pig retinal ganglion cells (RGCs) and to characterize the neuroprotective effect of acetylcholine (ACh) on pig RGCs.

Methods. Adult pig RGCs were isolated from other retinal tissue by a modified panning technique using Thy 1.1 antibody. Isolated RGCs were cultured in control media and media containing: glutamate, NMDA, or KA; glutamate and CNQX, MK801, or AP-7; ACh, nicotine or muscarine; ACh and $\alpha$-bungarotoxin (Bgt) or methyllycaconitine (MLA); and glutamate and choline or glutamate, choline, and MLA. To determine cell viability, cells were loaded with calcein and counted.

RESULTS. Ninety-eight percent of isolated cells were immunolabeled with Thy 1.1 antibody. Chronic exposure to $500 \mu \mathrm{M}$ glutamate decreased the number of surviving large and small RGCs, compared to control conditions. This glutamate-induced excitotoxicity was mediated through both NMDA and nonNMDA GluRs. In neuroprotective studies, ACh, nicotine, and choline significantly reduced glutamate-induced excitotoxicity in adult pig RGCs through $\alpha$-Bgt-sensitive nicotinic ACh receptors (nAChRs).

Discussion. This was the first report of a modified panning technique to isolate adult pig RGCs. Cell viability was relatively high using this method, and both large and small RGCs grew extensive neurites in culture. The finding that both NMDA and non-NMDA GluRs were involved in glutamate-induced excitotoxicity suggests that isolated pig RGCs provide a good model for glaucoma. In addition, activation of AChRs may be useful in protecting RGC from excitotoxic insults occurring in neurodegenerative diseases such as glaucoma. (Invest Ophthalmol Vis Sci. 2004;45:1531-1543) DOI:10.1167/iovs.03-0406

$\mathrm{E}$ xcitotoxicity, neuronal cell death caused by excessive activity, is linked to various diseases of the central nervous system $^{1,2}$ including the retina. In the retina, diseases associated with excitotoxicity include retinal ischemia, diabetic retinopathy, and glaucoma. ${ }^{3,4}$ Glaucoma is one of the leading causes of blindness in the world, affecting an estimated 66 million people. Although the fundamental cause of glaucoma is yet to be found, the primary risk factor associated with glaucoma is an increase in intraocular pressure. Several studies have identified

From the Department of Biological Sciences, Western Michigan University, Kalamazoo, Michigan.

Supported by Western Michigan University Neuroscience Jumpstart Award (CLL).

Submitted for publication April 23, 2003; revised August 11, 2003 and January 16, 2004; accepted January 20, 2004.

Disclosure: E. Wehrwein, None; S.A. Thompson, None; S.F. Coulibaly, None; D.M. Linn, None; C.L. Linn, None

The publication costs of this article were defrayed in part by page charge payment. This article must therefore be marked "advertisement" in accordance with 18 U.S.C. $\$ 1734$ solely to indicate this fact.

Corresponding author: Cindy L. Linn, Associate Professor, Department of Biological Sciences, Western Michigan University, $1903 \mathrm{~W}$ Michigan Avenue, Kalamazoo, MI 49008; cindy.linn@wmich.edu. an excess of the excitatory neurotransmitter, glutamate, in the vitreous humor. ${ }^{5-7}$ Previous studies have demonstrated that excess glutamate release in the eye leads to prolonged influx of nonspecific cations in retinal ganglion cells (RGCs) of the retina and triggers intracellular signaling cascades leading to apoptosis. ${ }^{8,9}$ RGCs are one of five main types of neurons in the vertebrate retina. The axons of the RGCs form the optic nerve, which acts to convey visual information to the brain. When RGCs die through excitotoxicity-induced apoptosis, loss of the visual field occurs.

Previous immunocytochemical, pharmacological, and in situ hybridization studies have demonstrated that RGCs contain both NMDA and non-NMDA ionotropic glutamate receptors (GluRs). ${ }^{10-13}$ In this study, we used cultured RGCs isolated from adult pig retina as a model for human disease, ${ }^{8,14}$ including glaucoma.,7 Pig RGCs were used in this study, instead of the more common rodent model, because of the conflicting results reported using rodent preparations concerning the types of glutamate receptors involved in glutamate-induced excitotoxicity. For instance, in mixed rat retinal cultures, a number of studies have demonstrated that RGCs are susceptible to NMDA-induced cell death. ${ }^{15-17}$ However, other studies using the rat model have demonstrated that both NMDA and non-NMDA receptors are required for excitotoxicity; ${ }^{18}$ still other rat model studies have demonstrated that glutamateinduced excitotoxicity is due solely to non-NMDA receptors. ${ }^{19}$

The purpose of this study was to characterize the specific GluR subtypes responsible for glutamate-induced excitotoxicity in adult pig cultured RGCs and to characterize a potential neuroprotective agent that promotes RGC survival. A growing body of evidence indicates that neuronal nicotinic acetylcholine receptors (nAChRs), in addition to mediating fast cholinergic transmission, may modulate other actions within the CNS. In particular, $\alpha 7$ nAChR has been linked to neuroprotection against glutamate-induced excitotoxicity in the brain. ${ }^{20-23}$ However, a potential neuroprotective role of acetylcholine $(\mathrm{ACh})$ in the retina remains unexplored. In the retina, cholinergic neurons are a well-described population of amacrine cells known as starbursts, due to their unique morphology. ${ }^{24,25}$ This population of cholinergic neurons is equally divided in the retina, with one group in the inner nuclear layer of the retina and the other group lying in the ganglion cell layer. ${ }^{25,26}$ The cholinergic starburst amacrine cells receive strong excitatory input from bipolar cells and synapse onto RGCs. ${ }^{27-31}$

In this study, we demonstrated that activation of $\alpha$-bungarotoxin (Bgt)-sensitive nicotinic ACh receptors in adult pig RGCs was linked to neuroprotection against glutamate-induced excitotoxicity. The type of ACh receptors involved in this process was characterized.

\section{Methods}

\section{Dissociation and Panning Procedure}

Pure RGCs were isolated from adult porcine eyes using a modified version of the two-step panning technique ${ }^{19,32}$ first described by Barres et al. ${ }^{33}$ Adult pig eyes were obtained immediately after slaughter from a local slaughterhouse and kept on ice for transport. Within 1 hour of 
eye removal, retinas were removed from the eyes and subsequently dissociated and isolated using the modified panning technique. To separate retina from the eye chamber, the cornea and lens were surgically excised from each eye, and the underlying lens and vitreous humor were manually removed. The remaining eyecup containing retina was placed in modified $\mathrm{CO}_{2}$-independent medium (Gibco, Carlsbad, CA; cat \# 18,045-088), maintained at $37^{\circ} \mathrm{C}$, containing $4 \mathrm{mM}$ glutamine, $10 \%$ fetal bovine serum (FBS), 5\% antibiotic/antimycotic, and $4 \mathrm{mM}$ HEPES, and the retina was manually peeled out of the eyecup. Isolated retinas were subsequently chopped into smaller fragments and enzymatically treated with papain $(27 \mathrm{u} / \mathrm{mg})$ for 20 minutes at $37^{\circ} \mathrm{C}$. After 20 minutes, enzymatic treatment was inactivated by rinsing tissue in fresh $37^{\circ} \mathrm{C} \mathrm{CO}$-independent medium containing 1 $\mathrm{mg} / \mathrm{mL}$ DNase. Once enzymatically treated, retinal tissue was fully dissociated by gentle trituration using an unpolished Pasteur pipette. Dissociated cells were then incubated in a $150 \times 15 \mathrm{~mm}$ Petri dish precoated with goat anti-rabbit IgG antibody (Jackson ImmunoResearch, West Grove, PA; cat \#111-005-003; $0.5 \mathrm{mg}$ in $10 \mathrm{~mL}$ of $20 \mathrm{mM}$ Tris buffer) for 1 hour at $37^{\circ} \mathrm{C}$ to eliminate nonspecific binding. This was the first panning step. Goat anti-rabbit IgG antibody had been applied and evenly disbursed over the Petri dish the evening before retina dissociation and kept at $4^{\circ} \mathrm{C}$ overnight. In the morning of the dissociation, IgG-treated Petri dishes were washed three times with PBS and washed once again with PBS containing $0.2 \%$ BSA for 20 minutes before removal and application of dissociated pig retina.

After 1 hour on the IgG plate, cells were transferred to another 150 $\mathrm{mm} \times 15 \mathrm{~mm}$ Petri dish coated with mouse anti-rat Thy 1.1 antibody (BD Biosciences, San Diego, CA; cat \# 554898; $12.5 \mu \mathrm{g}$ in $10 \mathrm{~mL}$ PBS containing no magnesium chloride and no calcium chloride) bound to goat anti-mouse IgM (Jackson ImmunoResearch; cat \# 115-005-075; $0.36 \mathrm{mg}$ in $10 \mathrm{~mL}$ of $20 \mathrm{mM}$ Tris buffer). This was the second panning step. To prepare this second panning plate, an IgM $150 \mathrm{~mm} \times 15 \mathrm{~mm}$ Petri plate was prepared 1 day before retinal dissociation using the same procedure described for the IgG plates. On the dissociation morning, unbound IgM was sucked off the Petri dish and Thy 1.1 was applied and maintained at $37^{\circ} \mathrm{C}$ before transferring cells from the IgG plate.

Cells remained on the IgM/Thy 1.1 plate for 1 hour at $37^{\circ} \mathrm{C}$ and the supernatant was subsequently discarded. RGCs bound to Thy 1.1 were released using $0.25 \%$ trypsin for 10 minutes at $37^{\circ} \mathrm{C}$. After 10 minutes, trypsin activity was stopped with $1 \mathrm{mg} / \mathrm{mL}$ soybean trypsin inhibitor and cells were strained. At this point, the cell density of the dissociated RGCs was calculated with a hemocytometer, cells were diluted and plated at a density of $1 \times 10^{5}$ cells/mL into 24 -welled culture dishes coated with poly-D-lysine/laminin and incubated at $37^{\circ} \mathrm{C}$. The $\mathrm{CO}_{2}$ independent medium was modified to contain: $10 \% \mathrm{FBS}, 5 \%$ antibiotic/ antimycotic, $4 \mathrm{mM}$ HEPES, $4 \mathrm{mM}$ glutamate, $15 \mu \mathrm{g} / \mathrm{mL}$ nerve growth factor (NGF), $500 \mu \mathrm{g} / \mathrm{mL}$ transferrin, and $10 \mathrm{mg} / \mathrm{mL}$ insulin. Survival of cultured cells in this medium was significantly enhanced compared to cells cultured in Dulbecco's modified Eagle's medium (DMEM)-F12 medium in $5 \% \mathrm{CO}_{2}$. In the modified $\mathrm{CO}_{2}$-independent medium, an average of $61 \%(\mathrm{SE} \pm 5$ ) cells survived the dissociation process and remained healthy for a minimum of 3 days. This was compared to an average of only $42 \%(\mathrm{SE} \pm 3$ ) cells that survived the dissociation process and remained healthy for a minimum of 3 days when cells were incubated in DMEM-F12 medium. Cell survival was determined by calcein fluorescence as described below.

After cells were allowed to settle for 2 hours, medium was replaced with fresh modified $\mathrm{CO}_{2}$-independent medium in each well. The first column of each 24-welled culture dish contained untreated control cells. The remaining five columns in each 24-well culture dish contained cells that were treated with appropriate agonists +/or antagonists. The RGCs in these five columns contained their appropriate pharmacological agents for period of $1,3,5$, or 7 days. After these time periods, cells were loaded with $2 \mu \mathrm{M}$ of membrane-permeable calcein for 1 hour to label living viable cells. ${ }^{34}$ In some experiments, $10 \mu \mathrm{M}$ calcein was used instead of $2 \mu \mathrm{M}$ to label neurites as well as cell bodies.
After the 1-hour incubation, living cells intensely fluoresce as a result of $495 \mathrm{~nm}$ excitation. Background fluorescence levels were inherently low with this assay technique because the calcein dye is virtually nonfluorescent before interacting with cells.

Microscopy was performed on a Nikon Diaphot epifluorescent research microscope illuminated by a $100-\mathrm{W}$ mercury arc lamp with an excitation filter EX 510 to 590, dichroic mirror DM 580, and barrier filter BA590. Fluorescent cells were recorded by a Hamamatsu XC-77 CCD camera, captured using a Metamorph Imaging system (Universal Imaging, Downingtown, PA) and counted using Imagepro software (Media Cybernetics, Inc., Silver Spring, MD). The number of living RGCs in pharmacologically-treated wells was compared to the number of living cells counted in the wells containing untreated control RGCs to obtain a percent change from control. A minimum of five animals was used to generate all pharmacological results. From each animal, cells were plated onto a minimum of four individual wells for each agent tested. Statistical analysis was performed on data using an analysis of variance (ANOVA) followed by linear contrast. $P<0.05$ was considered statistically significant. Statistical treatments were performed on data normalized to control values for each experimental series to minimize variation.

\section{Immunocytochemistry}

To ensure that all the panned cells were RGCs, some panned cells were processed immunocytochemically with an antibody specific for RGCs; Thy 1.1.35,36 Panned RGCs were plated onto coverslips and fixed in ice-cold $100 \%$ methanol for 10 minutes, washed three times with phosphate buffered saline (PBS), and blocked with $5 \%$ bovine serum albumin (BSA) in PBS. Primary mouse anti-rat Thy 1.1 antibody (1:100; BD Biosciences; CD90) was applied to fixed cells in 1\% BSA in PBS overnight at $4^{\circ} \mathrm{C}$. After 24 hours, coverslips were washed three times with $0.1 \%$ BSA in PBS and a secondary antibody linked to Alexa Fluor 488 (emission 494; Molecular Probes, Eugene, OR) was applied to cells for visualization at $1: 100$ in $1 \%$ BSA in PBS for 30 minutes at room temperature. After a secondary antibody treatment, coverslips were washed four times with $0.1 \%$ BSA in PBS. Coverslips were attached to slides using Slowfade antifade medium (Molecular Probes). Cells were photographed with a Hamamatsu XC-7CCD camera. To confirm that antibody staining was specific for the antigen, control slides were included in which the primary antibody was omitted.

\section{Pharmacological Treatment}

In some experiments, panned RGCs plated in columns 2 to 6 in 24-welled culture dishes were pharmacologically treated with glutamate, glutamate agonists, glutamate antagonists, ACh, ACh agonists, or ACh antagonists. In other experiments, a combination of these agents was applied. All agents were directly applied to individual culture wells to obtain a variety of agent concentrations. All agonists and antagonists were obtained from Sigma (St. Louis, MO): (agonists) glutamate, N-methyl-D-aspartate (NMDA), kainic acid (KA), ACh, choline, and nicotine; (antagonists) 6-cyano-7-nitroquino-xaline-2,3-dione (CNQX), 2-amino 7 phosphonoheptanoic acid (AP-7), 5 methyl-10,11-dihydro5H-dibenzo[a,d]cyclohepten-5,10-imine hydrogen maleate (MK-801), $\alpha$-bungarotoxin ( $\alpha$-Bgt), and methyllycaconitine, (MLA). Agonist and antagonist concentrations were determined from dose-response experiments. The minimal dosage that provided a maximum effect was used throughout the study.

\section{Results}

\section{Immunoreactivity to Thy 1.1 Antibody by All Panned Retinal Cells}

The panning technique used in this study was specifically designed for isolation of adult pig RGCs. To verify that pig RGCs were isolated from all other retinal cell types, panned 
FIGURE 1. Thy 1.1 antibody labeled all panned pig retinal cells. (A) Demonstrates a view of the immunostained panned cells after 3 day in culture under transmitted illumination. (B) Demonstrates the same field of immunostained panned cells under Alexa Fluor 488 fluorescence. (C) Represents another field of panned cells immunocytochemically processed with the primary antibody omitted. (D) Taken under transmitted illumination, demonstrates a view of immunostained retinal cells that were cultured but not panned to isolate the retinal ganglion cells from other retinal cells. (E) Taken under Alexa Fluor fluorescence. (F) The overlay of (D) and (E). Bar represents scale
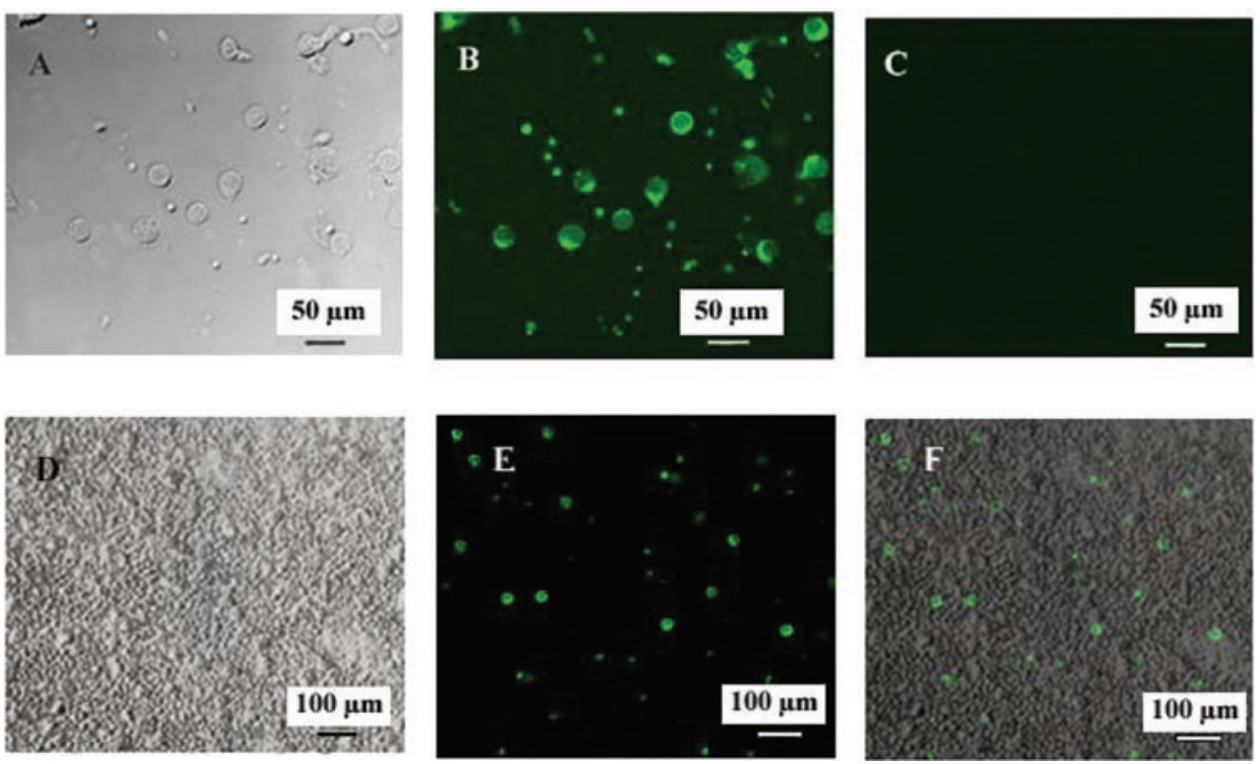

In Figure 2, RGCs were cultured for 3 days and loaded with retinal cells were immunostained with primary antibody specific for retinal ganglion cells, Thy 1.1. In Figure 1, adult pig RGCs were isolated by the two-step panning technique described in the Methods section, plated, and immunostained with primary antibody Thy $1.1(1: 100)$ and secondarily labeled with Alexa Fluor 488. Figure 1A demonstrates a typical image obtained from a culture dish containing immunostained panned retinal cells using transmitted illumination. In Figure 1B, the same field of cells labeled with Thy 1.1 antibody are visualized using Alexa Fluor 488 fluorescence. As seen in this example, every cell in the field was immunostained with Thy 1.1 antibody. This was typical of results obtained from all panned retinal cells and supported the hypothesis that the panning technique used in this study exclusively isolated pig retinal ganglion cells. In 48 culture wells containing panned cells, an average of $98.2 \%( \pm 3)$ of cells stained with Thy 1.1 antibody. The percentage of cultured cells that stained with Thy 1.1 antibody did not change whether cells were analyzed for Thy 1.1 immunostaining 1, 3, or 5 days after culture. At no time was there any evidence of other retinal neurons or glial growth in culture wells containing panned cells. In 48 cultured wells containing immunostained pig RGCs, the ratio of large to small RGCs was 1:3. As evident from the Thy 1.1 immunostained RGCs, large and small RGCs were isolated and labeled. Large RGCs had displaced nuclei similar to large pig RGCs immunostained with alternate antibodies. ${ }^{37}$ Figure $1 \mathrm{C}$ illustrates a field of panned cells immunocytochemically processed when the primary antibody was omitted.

When cells were not panned, labeling with Thy 1.1 antibody $(1: 100)$ was restricted to a subset of cells. To generate Figure 1D, an entire retina was enzymatically treated, dissociated, plated, and cultured for 3 days without using the modified two-step panning technique to isolate retinal ganglion cells from other retinal cells. Under these conditions, a monolayer of cells covered each plated culture well within 3 days. After 3 days, cells were processed with Thy 1.1 antibody according to the immunocytochemical procedures outlined in the Methods section. Figure 1D illustrates the field of view under transmitted illumination. Figure 1E illustrates the same field of cells labeled with Thy 1.1 antibody and visualized using Alexa Fluor 488 fluorescence. Omission of the panning step resulted in a mixed culture where only a fraction of cells were immunostained with Thy 1.1 antibody. An overlay of Figure 1D and Figure $1 \mathrm{E}$ is illustrated in Figure $1 \mathrm{~F}$.
$10 \mu \mathrm{M}$ calcein instead of $2 \mu \mathrm{M}$ calcein for 1 hour, which extensively labeled cell bodies as well as all processes. Large retinal ganglion cells exhibited large circular somata (30-45 $\mu \mathrm{m}$ in diameter) and typically had several fine smooth processes emerging from the cell body (arrows). The small RGCs had diameters $<20 \mu \mathrm{m}$ and were typically monopolar or bipolar with circular bodies (arrowheads), similar to results obtained from Luo et al. ${ }^{37}$

\section{Excitotoxic Effects of L-Glutamate and GluR Agonists on Adult Pig RGCs}

Chronically elevated glutamate in the vitreous humor of several species is associated with glutamate excitotoxicity and glaucoma. $^{5-7}$ In Figure 3, the effect of chronically elevated glutamate on adult pig RGCs is illustrated. Figure $3 \mathrm{~A}$ demonstrates the percentage of total panned pig RGCs that survive after

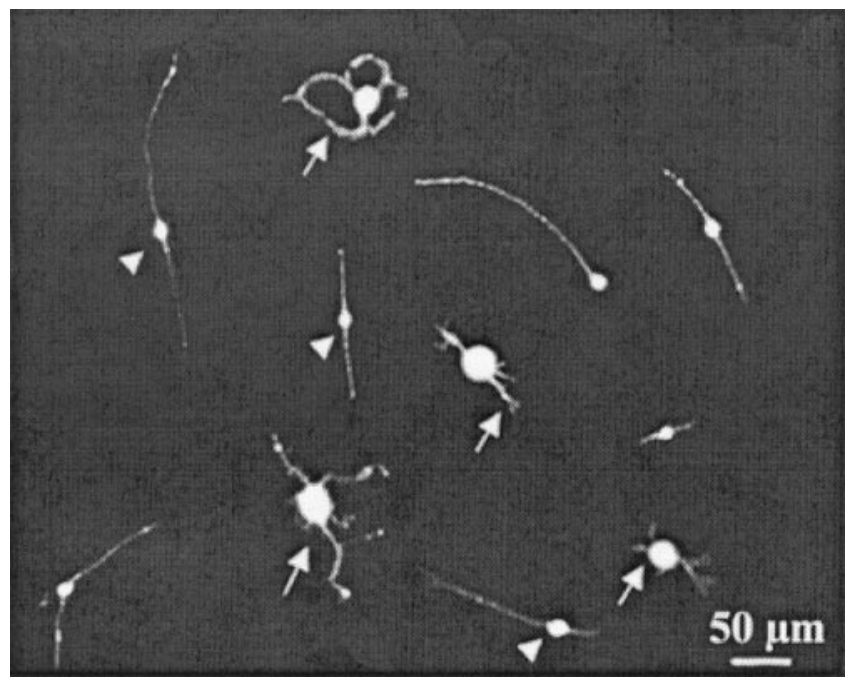

FigURE 2. Two morphologic types of adult pig RGCs. Adult pig retina was dissociated and isolated using the modified two-step panning technique. Bar represents scale. 

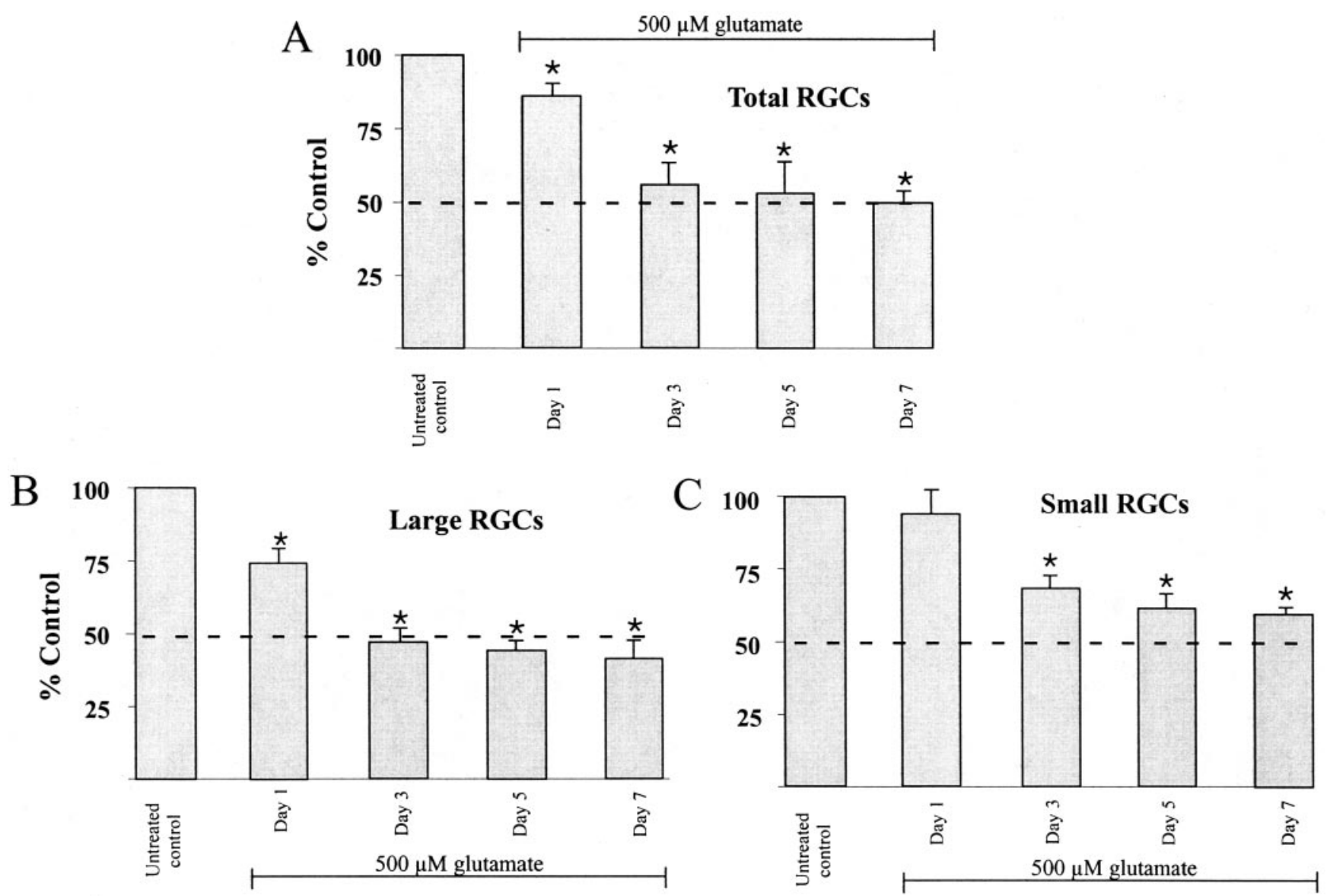

Figure 3. Chronic exposure of $500 \mu \mathrm{M}$ glutamate had excitotoxic effects on large and small pig RGCs. (A) Effect of $500 \mu \mathrm{M}$ glutamate on total survival of RGCs after 1, 3, 5, and 7 days in culture. (B) The effect of chronic glutamate on large RGCs. (C) The effect of chronic glutamate on small RGCs. (*) Significance from control $(P<0.05)$. Each bar graph represents the mean \pm SE $(n=$ seven experiments).

exposure to a relatively high concentration of L-glutamate for $1,3,5$ days, and 1 week. To obtain the data shown in Figure $3 \mathrm{~A}$, panned cells were exposed for various times to $500 \mu \mathrm{M}$ L-glutamate. Each bar graph represents the mean percent of cells that labeled with calcein compared to control calceintreated cells obtained from the same animal. Therefore, these graphs represent the mean percent of cells that survived experimental treatment. Data for all pharmacological studies were collected from 5 to 20 different animals.

After 1 day, there was a significant difference in survival between the groups of cells exposed to L-glutamate and control. As shown in Figure 3A, after only 1 day in culture, a mean of $85 \%$ of panned RGCs survived, compared to control conditions, and suggested that exposure of $500 \mu \mathrm{M}$ glutamate for 1 day had an excitotoxic effect on $15 \%$ of panned RGCs. However, the largest difference between treated and untreated cells occurred by day 3 where a mean of $58 \%( \pm 5)$ of cells survived in the presence of chronic $500 \mu \mathrm{M}$ L-glutamate compared to untreated cells, suggesting that glutamate had an excitotoxic effect on a mean of $42 \%$ of panned RGCs. These results support the hypothesis that chronic exposure to high concentrations of glutamate has an excitotoxic effect on adult pig RGCs. Figures $3 \mathrm{~B}$ and $3 \mathrm{C}$ demonstrate that there was a differential excitotoxic effect of chronic glutamate exposure on large and small RGCs. This was apparent by day 1 in culture, where there was a significant excitotoxic effect of L-glutamate on large RGCs compared to control conditions, but no significant difference observed in the percent of small RGCs compared to control conditions. However, after 3 days in chronic glutamate, there was a significant decrease in both large and small RGCs compared to control conditions, although the glutamate effect was greater on large RGCs compared to small RGCs $(P<0.05)$. The greater effect of glutamate on the larger RGCs compared to smaller RGCs remained through days 3, 5, and 7. Because glutamate exerted its maximal excitotoxic effect on large and small RGCs by the third day in culture, all cultured cells in subsequent experiments were exposed for 3 days.

In the described experiments, isolated RGCs were exposed to glutamate and agonists within a few hours of dissociation. Because the dissociation process can cause severe enzymatic and mechanical insults on the cells and can potentially affect expression of surface receptors involved in excitotoxicity or neuroprotection, experiments were repeated on RGCs that were cultured for longer periods of time in control medium before addition of any pharmacological agent. We found that the timing of agonist application to panned RGCs had no effect on cell survival. For instance, glutamate caused the same degree of excitotoxicity to panned RGCs whether it was applied to recently cultured cells (within 6 hours) or whether it was applied to cells allowed to settle for 24,48 , or 36 hours before glutamate application (data not shown). Due to this result, all pharmacological agents were applied to recently cultured cells for convenience.

The time-course of glutamate-induced excitotoxicity is demonstrated in Figure 4. As shown in this figure, a percentage of RGCs are destroyed during the dissociation and modified pan- 


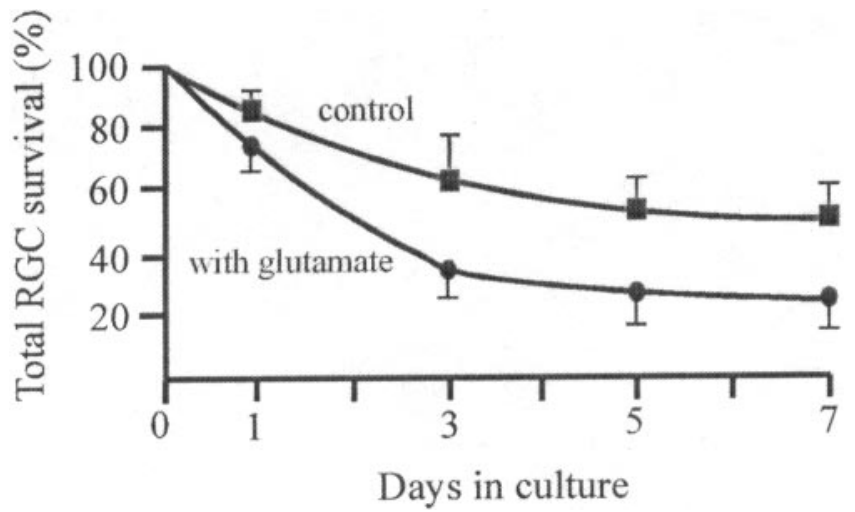

Figure 4. Time course of cell survival. Solid squares: the mean percentage of cells that survived in cultures in the absence of glutamate from days 1 through 7 . Solid circles: the mean percentage of cells that survived in cultured in the presence of $500 \mu \mathrm{M}$ glutamate. Data points were curve fit. Each point represents the mean of between five and twenty experiments. Error bars represent SE.

ning process described in this study, and cell survival gradually decreased over a 7-day period, typical of cells in culture. Without glutamate treatment (solid squares), cell survival gradually decreased from $100 \%$ to $60 \%$ survival over the first 7 days in culture. However, with glutamate treatment (solid circles), cell survival decreased significantly compared to control conditions for each day 1 to $7(P<0.05)$.

Glutamate dose-response curves were obtained from panned pig RGCs at 3 days exposure for large RGCs (Fig. 5A), small RGCs (Fig. 5B), and total RGCs (Fig. 5C). Glutamate had measurable excitotoxic effects on large RGCs at concentrations as low as $50 \mu \mathrm{M}$ and had a maximal effect in the presence of $500 \mu \mathrm{M}$ glutamate. The $\mathrm{ED}_{50}$ for the excitotoxic effect of glutamate on large RGCs was $325 \mu \mathrm{M}$ (Fig. 5A). In Figure 5B, the dose-response curve for small RGCs was demonstrated. Glutamate had a threshold excitotoxic effect in the presence of $100 \mu \mathrm{M}$. Similar to the results obtained with large RGCs, a maximal excitotoxic plateau effect was measured on small RGCs in the presence of $500 \mu \mathrm{M}$ glutamate. The $\mathrm{ED}_{50}$ value for small RGCs was $285 \mu \mathrm{M}$. In Figure 5C, the dose-response curve for total RGCs was demonstrated. A measurable threshold change in cell survival was measured in the presence of 50 $\mu \mathrm{M}$, the maximal plateau effect was elicited in the presence of
$500 \mu \mathrm{M}$ glutamate, and the $\mathrm{ED}_{50}$ for the excitotoxic effect of glutamate on total pig RGCs was $302 \mu \mathrm{M}$. $500 \mu \mathrm{M}$ glutamate was used for all subsequent experiments, as it represented the minimum effective dose that elicited maximal excitotoxic effects on both large and small RGCs.

RGCs contain both NMDA and non-NMDA type GluR subtypes. Since L-glutamate is the endogenous agonist for all retinal GluRs, experiments were performed to determine what type of GluR subtypes were responsible for the excitotoxic effect of glutamate on panned RGCs. Cells were cultured in the presence of the glutamate agonists, NMDA or KA (Fig. 6). A concentration range of KA or NMDA was applied for 3 days and results were compared between treated and untreated control cells. Ten $\mu \mathrm{M} \mathrm{KA}$ had no significant effect on panned RGCs. However, concentrations as low as $50 \mu \mathrm{M}$ KA significantly reduced the number of RGCs compared to controls and maximal excitotoxic effects occurred in the chronic presence of $100 \mu \mathrm{M} \mathrm{KA}$, suggesting that KA receptors are at least partially responsible for glutamate excitotoxicity recorded from panned pig RGCs. Because maximal activation of KA receptors did not mimic the degree of excitotoxicity caused by $500 \mu \mathrm{M}$ glutamate, it is possible that other GluR subtypes may be involved in glutamate excitotoxicity. Concentrations of NMDA as low as $100 \mu \mathrm{M}$ significantly reduced the percent of panned RGCs by a mean of $17 \%$ compared to control conditions when cultured in media containing normal magnesium (Fig. 6A). However, unless cells are depolarized from their resting membrane potential, the voltage-dependent magnesium block characteristic of NMDA receptors would reduce the contribution of NMDA receptors to the excitotoxic effect of glutamate on pig RGCs. This was addressed by experiments where KA and NMDA were co-applied to panned pig RGCs (Fig. 6B). Under these conditions, KA can bind to KA/AMPA GluRs to open nonspecific cation channels and depolarize the RGCs. After depolarization and removal of the magnesium-induced voltage-dependent block of NMDA receptors, NMDA receptors should be activated. From the results summarized in Figure $6 \mathrm{C}$, the combination of $100 \mu \mathrm{M} \mathrm{KA}$ and NMDA mimicked the total excitotoxic effect of $500 \mu \mathrm{M}$ glutamate. Taken together, these results suggested that both KA and NMDA receptors are involved in the excitotoxic effect of glutamate observed on pig RGCs.

To confirm that both non-NMDA and NMDA GluR subtypes were involved in glutamate excitotoxicity in pig RGCs, experiments using specific antagonists were conducted. In Figure 7 , various concentrations of the KA specific antagonist, CNQX,
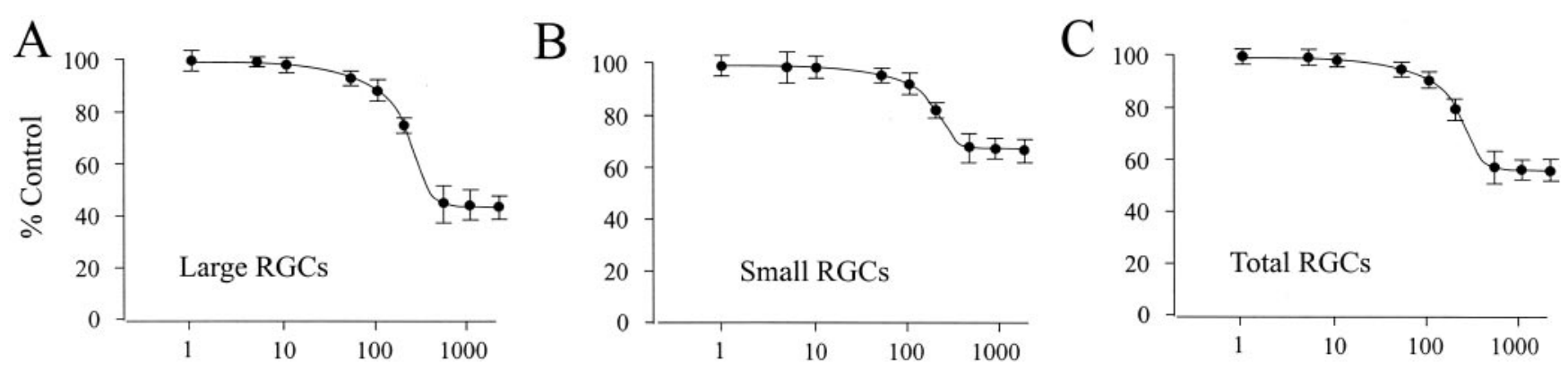

L-glutamate concentration $(\mu \mathrm{M})$

Figure 5. Glutamate dose-response curves. Various concentrations of L-glutamate were applied to panned RGCs for 3 days. Cells were counted after 3 days and the percent of cells that survived after 3 days were compared to control untreated cells and plotted. Each solid data point represents the mean of between 20 to 50 cultured wells obtained from between five and twenty different adult pigs. (A) The dose-response curve obtained when counting only large RGCs. (B) The dose-response curve obtained when counting only small RGCs. (C) The glutamate dose-response curve obtained when total panned RGCs are counted. Each data point represents the mean percent of cells that survived compared to control conditions. Data points were curve fit using the Hill equation. Error bars represent SE. 
A
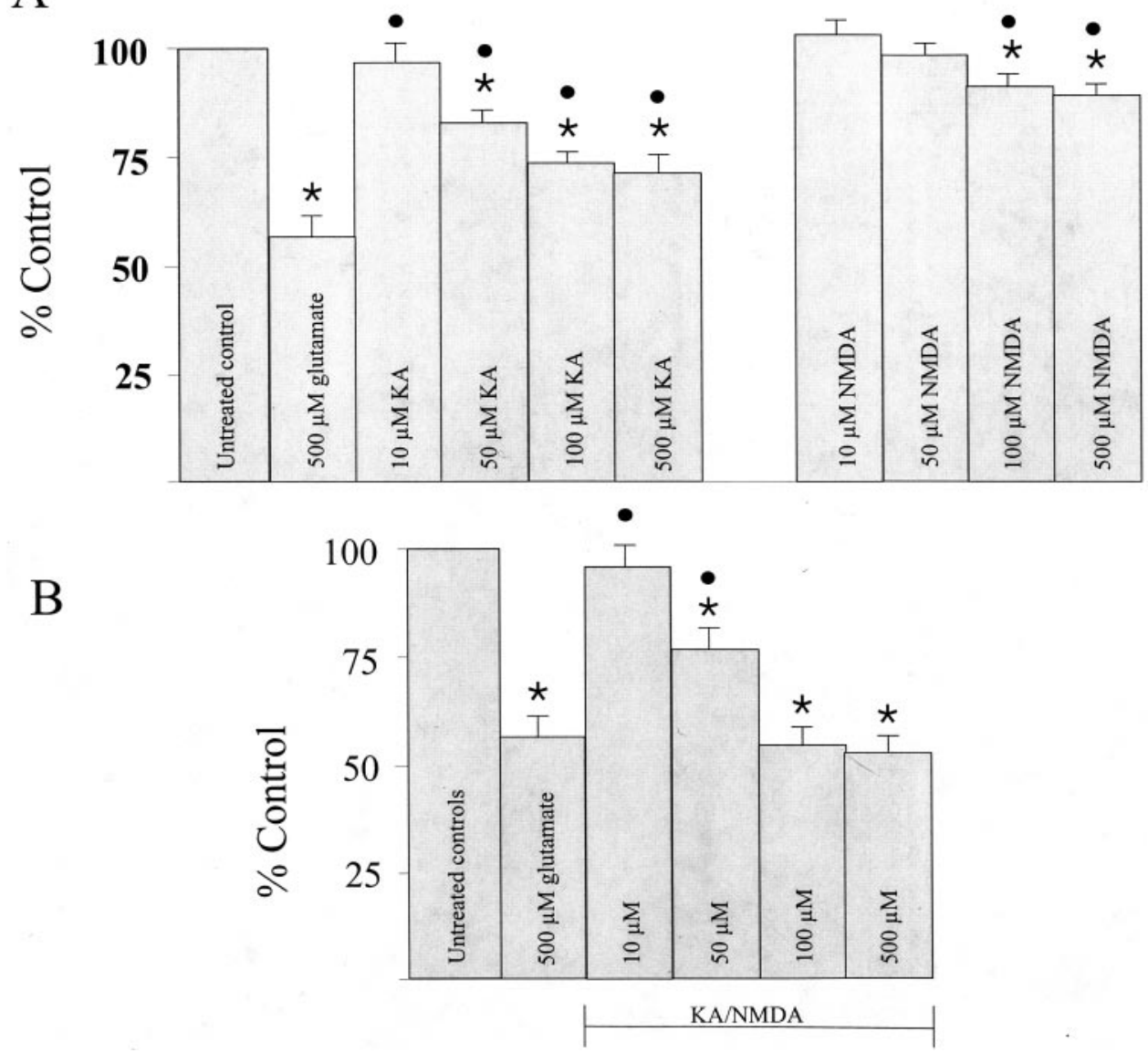

Figure 6. Glutamate and glutamate agonists have excitotoxic effects on panned RGCs. (A) Effect of $500 \mu \mathrm{M}$ glutamate on RGC survival and various concentrations of two glutamate agonists on RGC survival; KA and NMDA. (B) The effect of co-applying various concentrations of $\mathrm{KA}$ and NMDA. Asterisks: significance from control; solid circles: significance from $500 \mu \mathrm{M}$ glutamate $(P<0.05)$. Each bar graph represents the mean $\pm \mathrm{SE}(n=$ six experiments).

were applied to panned adult pig RGCs before chronic exposure to $100 \mu \mathrm{M}$ KA. Although $100 \mathrm{nM}$ CNQX had no significant effect on KA-induced excitotoxicity, when cells were pretreated in concentrations of CNQX equal or greater than a threshold dose of $10 \mu \mathrm{M}, \mathrm{KA}$ effects were eliminated (Fig. 7A). Figures $7 \mathrm{~B}$ and $7 \mathrm{C}$ demonstrate that the competitive NMDA antagonist, AP-7, and the noncompetitive NMDA antagonist, MK-801, block the small but significant excitotoxic effect of NMDA on pig RGCs. Pretreatment of RGCs with $10 \mu \mathrm{M}$ CNQX and $100 \mu \mathrm{M}$ AP-7 or $100 \mathrm{nM}$ MK-801 virtually eliminated the combined excitotoxic effect of KA and NMDA (Fig. 7D).

If glutamate-induced excitotoxicity is due to activation of a combination of NMDA and non-NMDA GluRs, it follows that a combination of the GluR antagonists specific for NMDA and non-NMDA GluRs should eliminate the effect of glutamate on panned RGCs. When cells were pretreated with CNQX, MK801, or AP-7, glutamate-induced cell excitotoxicity was significantly reduced, but not blocked (Fig. 7E). However, when a combination of $10 \mu \mathrm{M}$ CNQX and $100 \mathrm{nM}$ MK-801 or $10 \mu \mathrm{M}$ CNQX and $100 \mu \mathrm{M}$ AP-7 were used, glutamate-induced excitotoxicity of panned RGC was completely eliminated. Taken together, these inhibition studies further support the hypothesis that glutamate-induced excitotoxicity of pig RGCs is mediated through a combination of NMDA and non-NMDA GluRs.

\section{Neuroprotective Effect of Acetylcholine on Panned RGCs}

Neuronal nAChRs play a role in neuroprotection of hippocampal and cortical neurons in the central nervous system. ${ }^{20-23}$ However, although nAChRs exist on vertebrate RGCs, ${ }^{28,38,39}$ it is not presently known if activation of these AChRs is linked to activation of a neuroprotection mechanism. In this study, the effect of ACh and nicotine on glutamate-induced excitotoxicity using panned adult pig RGCs were examined.

Figure 8 illustrates the summarized results obtained when panned pig RGCs were chronically exposed to $500 \mu \mathrm{M}$ glutamate for 3 days in the presence of various concentrations of ACh (Fig. 8A) and the ACh agonists, nicotine (Fig. 8B) or muscarine (Fig. 8C). As evident from the data summarized in Figure 8A, when cells were pretreated for 2 hours in $5 \mu \mathrm{M} \mathrm{ACh}$ before addition of $500 \mu \mathrm{M}$ glutamate, glutamate excitotoxicity in pig RGCs was completely eliminated. Similar results were obtained if cells were pretreated in 1 to $10 \mu \mathrm{M}$ nicotine (Fig. $8 \mathrm{~B})$ and supported the hypothesis that $\mathrm{ACh}$ has a neuroprotective effect on glutamate-induced excitotoxicity of panned pig RGCs and that the effect is mediated through a nicotinic ACh receptor subtype. However, when relatively high concentrations of ACh or nicotine $(50 \mu \mathrm{M})$ were applied before glutamate, the significant neuroprotective effect was lost (right bars, Figs. $8 \mathrm{~A}$ and $8 \mathrm{~B}$ ). This is likely due to nonspecific activity or toxic effects of these agents at high concentrations. When applied alone, $5 \mu \mathrm{M} \mathrm{ACh}$ or $1 \mu \mathrm{M}$ nicotine had no significant effect on the survival of RGCs (data not shown).

Neuronal nAChRs are linked to the opening of nonspecific cation channels, whereas muscarinic ACh receptors are linked to activation of G-proteins and second messenger systems. To determine if muscarinic ACh receptors on pig RGCs are involved in neuroprotection of glutamate-induced excitotoxicity, panned RGCs were pretreated with various concentrations of muscarine for 2 hours before application of $500 \mu \mathrm{M}$ glutamate. 

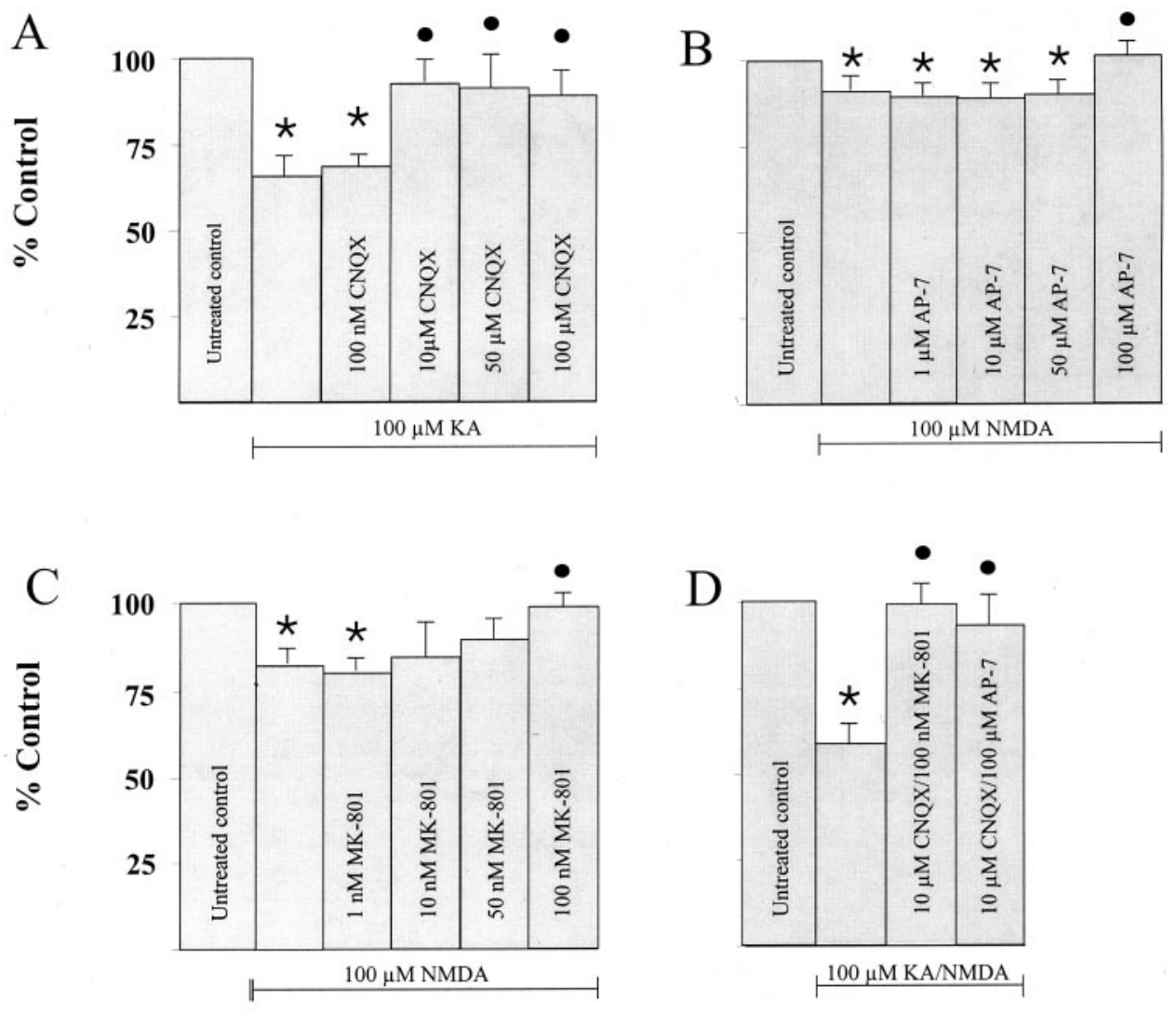

FigURE 7. Glutamate antagonists prevent excitotoxicity. Bar graphs demonstrating the effects of: (A) CNQX on KA-induced excitotoxicity; (B) AP-7 on NMDA-induced excitotoxicity; (C) MK-801 on NMDA-induced excitotoxicity; (D) a combination of CNQX and MK-801 or AP-7 on the excitotoxic effect induced by a combination of KA and NMDA; (E) CNQX, MK-801, AP-7, a combination of CNQX and AP-7, or a combination of CNQX and MK-801 on chronic glutamate exposure. Each bar graph represents the mean $\pm \operatorname{SE}(n=$ five experiments).

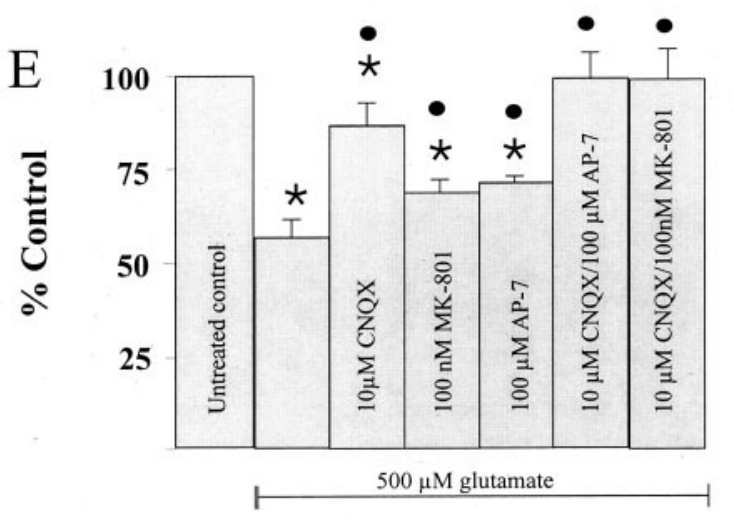

Muscarine had no significant neuroprotective effect on panned RGCs, even at relatively high concentrations (Fig. 8C).

\section{Partial Mediation of ACh Neuroprotection through $\alpha 7$ Nicotinic ACh Receptors}

Eleven neuronal nAChRs can be pharmacologically grouped into $\alpha$-Bgt-sensitive and $\alpha$-Bgt-insensitive agents. Neuronal nAChRs of the $\alpha$-Bgt-sensitive class contain $\alpha 7$ subunits and account for most of the $\alpha$-Bgt binding in the vertebrate brain. ${ }^{40}$ Numerous investigators have examined the role of $\alpha 7 \mathrm{nAChRs}$ in neuroprotection against glutamate-induced excitotoxicity in several regions of the CNS, ${ }^{67,74,80}$ excluding the retina. In this study, experiments were performed on panned pig RGCs to determine whether the neuroprotective effect of ACh and nicotine is mediated through $\alpha 7 \quad \alpha$-Bgt-sensitive nAChRs. Panned RGCs were pretreated for 2 hours in various concentrations of $\alpha$-Bgt before addition of $5 \mu \mathrm{M}$ ACh and 4 hours before addition of $500 \mu \mathrm{M}$ glutamate. Previous agents were not washed out as new additions were made, producing a final media cocktail containing all of the above-mentioned agents. Although $1 \mathrm{nM} \alpha$-Bgt blocked the neuroprotective effect of ACh by $10 \%, 10 \mathrm{nM} \alpha$-Bgt reduced its neuroprotective effect on panned RGCs by a mean of over 90\% (Fig. 9A). When ACh was replaced with nicotine, $\alpha$-Bgt had similar effects on blocking neuroprotection. As shown in Figure 9B, the neuroprotective effect of $1 \mu \mathrm{M}$ nicotine was significantly reduced when panned cells were pretreated with $1 \mathrm{nM} \alpha$-Bgt. However, when cells were incubated in $10 \mathrm{nM} \alpha$-Bgt, the neuroprotective effect of nicotine on panned RGCs was blocked by a mean of $95 \%$ (Fig. 9B).

These initial pharmacological studies supported the hypothesis that $\alpha$-Bgt-sensitive $\alpha 7 \mathrm{nAChR}$ subunits were responsible for the neuroprotective effect of ACh. However, much of the commercially available $\alpha$-Bgt contains small amounts of contaminants that can affect other nAChR subunits. To address this issue, further pharmacological experiments were performed 

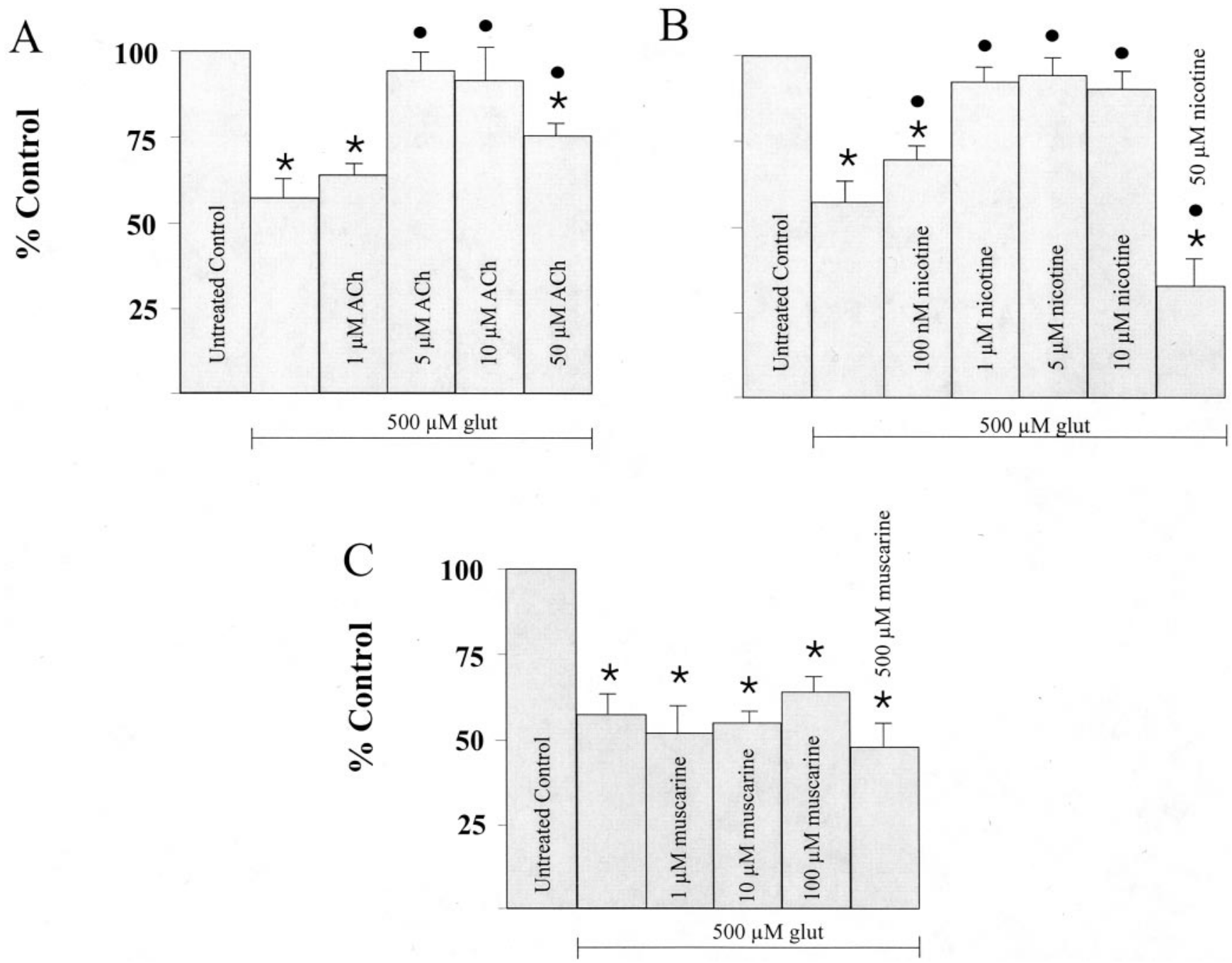

FIGURE 8. ACh and ACh agonists on total RGC survival. Bar graphs demonstrate the effects of ACh (A), nicotine (B), and muscarine (C) on glutamate-induced excitotoxicity. Each bar graph represents the mean \pm SE ( $n=$ five experiments).

using the $\alpha 7$ antagonist, methyllycaconitine (MLA), and the $\alpha 7$ agonist, choline.

MLA is an $\alpha$-Bgt-sensitive nAChR antagonist, highly selective for $\alpha 7 \mathrm{nACh}$ receptors when used at concentrations between 1 to $10 \mathrm{nM}$ in most preparations, ${ }^{41,42}$ although it binds to non- $\alpha 7$ nAChRs at low concentrations in dopaminergic neurons of the substantia nigra and ventral tegmental area. ${ }^{43}$ At higher concentrations, MLA also affects other nAChRs subunits, ${ }^{44,45}$ that are likely to be expressed in pig retina. ${ }^{46}$ In inhibition studies, when panned RGCs were pretreated with various concentrations of MLA before ACh and L-glutamate, 10 nM MLA significantly reduced the neuroprotective effect of ACh and nicotine (Figs. 9C and 9D). However, inhibition of the neuroprotective effect was maximized when cells were pretreated with 100 nM MLA, which blocked the neuroprotective effect of ACh by a mean of $98 \%$ and that of nicotine by $100 \%$ (Figs. 9C and 9D).

The finding that a relatively high concentration of MLA was required to block ACh neuroprotection supported the hypothesis that multiple nAChR subunits are involved in the neuroprotective effect of ACh. This idea was further supported in experiments using choline (Fig. 10). To determine the contribution of the $\alpha 7$ nAChRs to ACh-induced neuroprotection, cells were panned in the presence of $1 \mathrm{mM}$ choline $\left(\mathrm{EC}^{50}=\right.$
400 to $500 \mu \mathrm{M})$ and L-glutamate for 3 days. At this concentration, choline is a full agonist at $\alpha 7$ nAChRs. ${ }^{47,48}$ At higher concentrations, choline can act as a partial agonist for $\alpha 3 \beta 4$ or $\alpha 4 \beta 4$ nAChRs. ${ }^{49,50}$ As demonstrated by the bar graphs in Figure 10 , after 3 days in culture, $75.8 \%( \pm 3.2)$ of panned RGCs survived compared to $58 \%$ of RGCs that typically survive in the presence of $500 \mu \mathrm{M}$ L-glutamate alone. In inhibition studies, pretreatment of cells in $10 \mathrm{nM}$ MLA completely eliminated the neuroprotective effect of choline on glutamate-induced excitotoxicity in pig panned RGCs (Fig. 10). Taken together, these results strongly supported the hypothesis that ACh neuroprotection is partially mediated through $\alpha 7$ nAChRs, but additional nAChR subunits are also likely to be involved.

\section{Discussion}

The present study is the first to isolate pure adult pig RGCs using a two-step panning technique with Thy 1.1 antibody. Ninety-eight percent of cultured RGCs were immunolabeled with Thy1.1 antibody, verifying the purity of the culture. This was in agreement with findings in other animal models ${ }^{32}$ and confirmed the specificity of the Thy 1.1 antibody for RGCs. Based on morphologic features, adult pig RGCs immunostained 

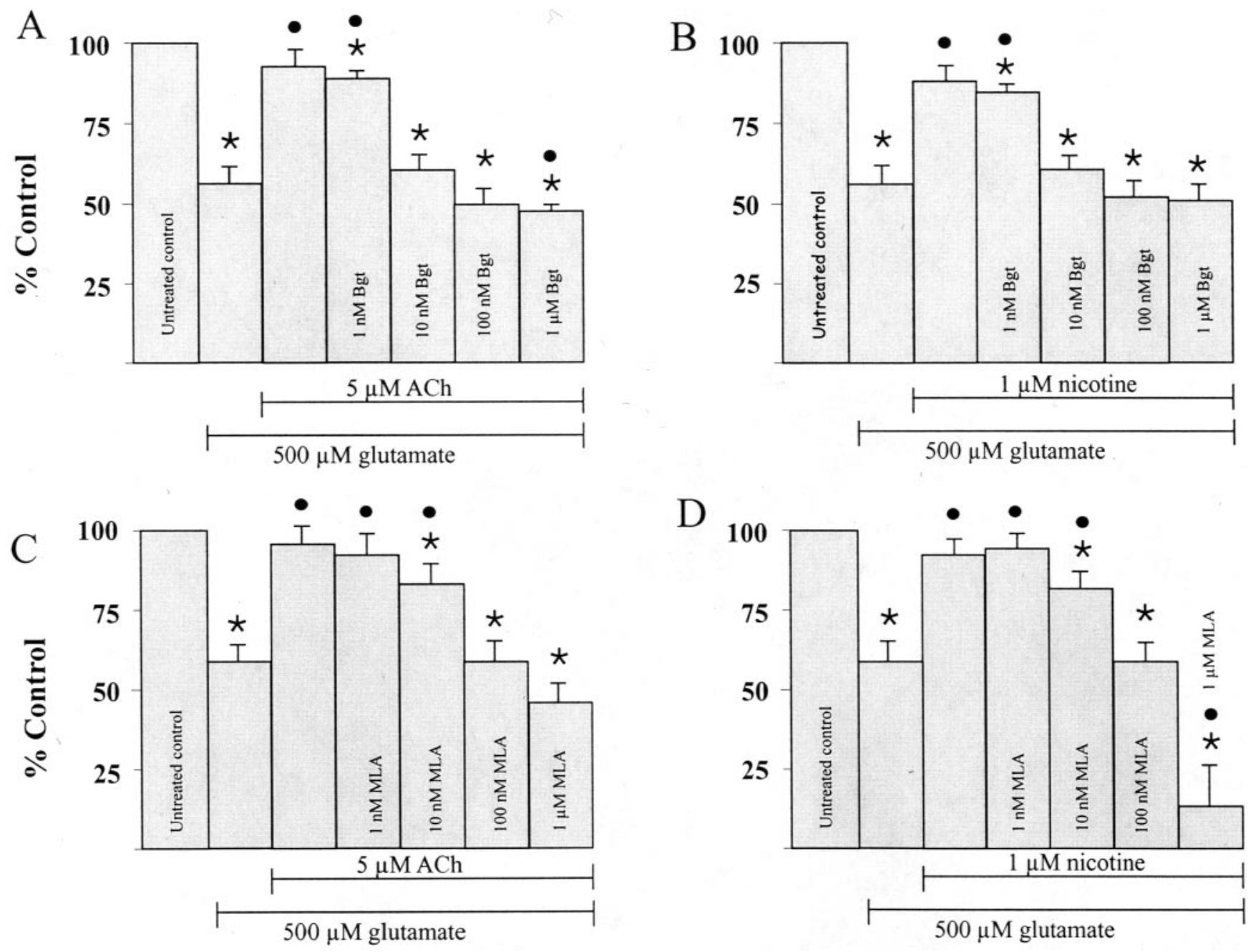

FIGURE 9. The neuroprotective effect of ACh on glutamate-induced excitotoxicity is inhibited by $\alpha$-Bgt (A) and MLA (C). In (B) and (D), the effect of various concentrations of $\alpha$-Bgt and MLA on the neuroprotective effect of nicotine on glutamate-induced excitotoxicity is demonstrated. Each bar graph represents the mean $\pm \mathrm{SE}(n=$ five experiments $)$.

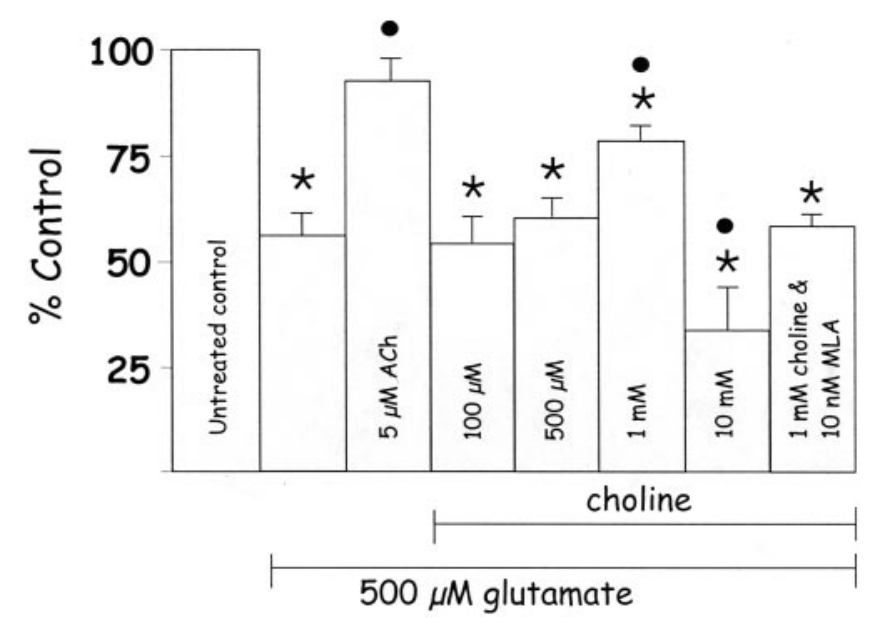

FIGURE 10. ACh neuroprotection is partially mediated through activation of $\alpha 7 \mathrm{nAChR}$ subunits. Bar graphs demonstrate the effect of various concentration of choline on glutamate-induced excitotoxicity and the effect of 10 nM MLA on choline's neuroprotection. Each bar graph represents the mean $\pm \mathrm{SE}$ ( $n=$ five to ten experiments). with Thy 1.1 were subdivided into two groups: small and large cells, similar to those characterized by Luo and associates ${ }^{37}$ in a mixed retinal culture. Immunostaining with Thy 1.1 was localized on somas of both large and small pig RGCs with little staining on neurites. This predominance of staining on pig RGC bodies differs from the staining pattern previously described in intact retinas of chick, rodent, and cats, ${ }^{35,51,52}$ where Thy 1 primarily labeled the interplexiform layer and stained the ganglion cell layer to a lesser degree. The difference in Thy 1 staining patterns between these species could be due to a variety of factors. For instance, in the cat retina, Thy 1 was found in the inner nuclear layer as well as in the inner plexiform and ganglion cell layer and represents a retinal distribution pattern different from that seen in other species. ${ }^{52}$ Therefore, species difference could account for differences observed. In addition, pig RGCs were fixed in 100\% methanol instead of the $4 \%$ paraformaldehyde used in all other studies of Thy 1 antibody. Different fixations have dramatic effects on immunostaining patterns in other systems ${ }^{53}$ and could explain the difference in staining pattern. Also, pig RGCs were incubated in primary antibody overnight compared to the 30minute incubation time associated with other studies using antibodies against Thy 1, which could explain the different 
immunostaining pattern present on pig RGC bodies compared to other species. Lastly, the difference in staining pattern may be due to the dissociation process. As seen in Figures 1 and 2, dissociated RGCs have fewer neurites than those identified in the intact retina. Fewer neurites and other changes that occur in the cells due to the dissociation process are likely to account for the labeling disparity.

The modified two-step panning technique allowed the determination of the concentration at which glutamate was toxic to adult pig RGC in vitro. A concentration of at least $500 \mu \mathrm{M}$ glutamate induced maximal cell death of large and small RGCs after chronic exposure for 3 days. Large RGCs were affected first in a fashion similar to the pattern of loss seen in glaucoma. ${ }^{14}$ Significant loss of large RGCs to $500 \mu \mathrm{M}$ glutamate occurred within 1 day, whereas significant loss of small RGCs to glutamate took 3 days. Also in agreement with in vivo studies, ${ }^{14,15,54}$ the loss of large RGCs was significantly larger than the loss of small RGCs at 1, 3, 5, or 7 days in culture. These results are in contrast to the study by Luo et al., ${ }^{37}$ who examined the effects of glutamate on an unpanned mixed retinal culture. Under mixed culture conditions, there was a selective, dose-dependent loss of large RGCs due to excess glutamate exposure but small RGCs were resistant to glutamate. It is possible that the different culture environments used in the two studies explains this discrepancy. In the mixed retinal culture, the myriad of different cell types, including glia, may act to bind or transport glutamate away from the RGCs and effectively reduce the concentration of glutamate present in the culture. This suggestion is consistent with the finding that larger concentrations of glutamate were needed in the mixed retina culture system to induce large RGC death compared to the concentrations of glutamate used on panned RGCs.

The present study supported the hypothesis that both NMDA and non-NMDA receptors are involved in adult pig RGC excitotoxicity, based on the finding that a combination of KA and NMDA was required to mimic glutamate excitotoxicity. Neither KA nor NMDA alone was sufficient to account for the total excitotoxic effect of glutamate. KA had the largest effect on RGC survival compared to NMDA. However, because magnesium was present in the culture media, the result of NMDA alone on pig RGCs was diminished due to the voltage-dependent magnesium block characteristic of NMDA receptors. ${ }^{55}$ To better evaluate the contribution of the NMDA receptor on RGC excitotoxicity, KA and NMDA were co-applied. Under these conditions, KA would activate non-NMDA GluR channels, allowing permeation of nonspecific cations, depolarization of RGCs to remove the NMDA receptor voltage-dependent magnesium block and permeation of ions through NMDA receptor channels. Co-application of KA and NMDA accounted for $100 \%$ of the glutamate-induced excitotoxic effect. The combined excitotoxic effect of KA and NMDA was totally eliminated only when cells were pretreated with a combination of NMDA and non-NMDA specific antagonists.

In vivo, glutamate receptors on RGCs are largely found on the dendrites and not on the somata. ${ }^{56,57}$ Due to the dissociated in vitro system used in this study, it is likely that the expression patterns of glutamate and $\mathrm{ACh}$ receptors on panned RGCs differ considerably from that of RGCs in vivo. Therefore, agents in this study were applied to activate agonist-specific soma receptors as well as dendritic receptors. This raises a concern common to any in vitro system. If the dissociation process has changed the expression pattern of receptors and likely other cell properties, how can results from an in vitro system accurately represent what is happening in an in vivo system? From the results of this study, the data strongly support the hypothesis that both NMDA and non-NMDA receptors were involved in glutamate-induced excitotoxicity in pig
RGCs. However, if the intact pig retina only contained nonNMDA receptors at dendritic synapses, it may be that only non-NMDA receptors played a role in excitotoxicity under physiological conditions. Experiments are currently underway to identify the receptor expression of pig RGC glutamate and ACh receptors in culture as well as in vivo.

\section{Excitotoxicity}

Both KA/AMPA and NMDA channels on vertebrate RGCs are permeable to calcium ions, ${ }^{58-60}$ which is a likely intracellular signal that acts to trigger downstream signaling pathways leading to apoptosis. Although the exact apoptosis signals in RGCs are unclear at present, a variety of such signaling pathways in other systems have been identified. These include, but are not limited to, signaling pathways linked to mitochondrial calcium overload with subsequent cytochrome $\mathrm{C}$ release, ${ }^{61}$ free radical production (nitric oxide, peroxide anion), ${ }^{62,63}$ p38 mitogen activated protein kinase (MAPK)-induced activation of MEF2 transcription factor, ${ }^{64,65}$ cytokine-induced activation of extracellular signal-regulated kinase (ERK), ${ }^{66}$ tyrosine phosphorylation of Janus kinase 2 and subsequent activation of AKT, ${ }^{67}$ and caspase activation with DNA fragmentation. ${ }^{68}$ Although it is not known which, if any, of these mechanisms are involved in RGC excitotoxic death, activation of both NMDA and nonNMDA receptors could create increases of intracellular calcium that are pathologic to the cells. Overall, large increases in intracellular calcium act as a second messenger to change the baseline activity of numerous enzymes that lead to apoptotic cascades and eventual cell death.

\section{Neuroprotective Mechanisms}

In previous studies, many laboratories have examined a variety of ways to prevent glutamate-induced excitotoxicity. Using pharmacological approaches, some studies have confirmed the importance of both NMDA and non-NMDA receptors in the mechanism underlying RGC death with the neuroprotective action of specific GluR antagonists., ${ }^{97,37,69}$ Other pharmacological agents that do not directly affect GluRs have neuroprotective effects, including adrenergic $\alpha 2$ agonists, ${ }^{4,70}$ beta 1 antagonists, ${ }^{71}$ and neurotrophic factors. ${ }^{72}$ In addition, other studies demonstrate that a low $\mathrm{pH}$ medium will protect retinal neurons from glutamate-induced delayed death through a proton modulation site on NMDA-operated channels ${ }^{73}$ and that NO-related species will react with critical cysteines on the NMDA receptor to prevent neuronal apoptosis. ${ }^{68,74}$

Nonpharmacological approaches to neuroprotection include preconditioning and activation of immunity. Preconditioning refers to strategies where subthreshold injuries induce an endogenous neuroprotective signal. ${ }^{69,75}$ Attempts are currently underway to isolate this endogenous signal. Other laboratories have demonstrated that certain types of immune activation positively correlate with retinal ganglion cell survival in retinal ganglion cell injury. ${ }^{76,77}$ It is hoped that this research may lead to a vaccine-like therapy for glaucoma. ${ }^{78}$

Although a variety of agents have a neuroprotective effect on RGCs in other systems, this study is the first to determine that relatively low concentrations of ACh and nicotine have a neuroprotective effect on panned adult pig RGCs against glutamate-induced excitotoxicity. The action of ACh and nicotine on RGCs was mediated exclusively through nAChRs, as muscarine failed to mediate any protection. The inefficiency of muscarinic receptors to mediate neuroprotection was also observed by Donnelly-Roberts et al. ${ }^{79}$ who found that the muscarinic receptor antagonist, atropine, did not block the neuroprotective effects of a cholinergic channel activator in rat primary cortical cell cultures. 
Accumulating evidence from other studies suggest that the neuroprotective action of ACh in the brain is mediated through $\alpha$-Bgt-sensitive $\alpha 7$ neuronal nAChRs, ${ }^{74}$ that transduce signals to phosphatidylinositol 3-kinase to block $\beta$-amyloid-induced neurotoxicity. ${ }^{80}$ Activation of $\alpha 7$ nAChRs in the brain triggers JAK2 and activation of phosphatidylinositol 3 (PI3)- kinase and Bcl-2, enzymes involved in cell survival which contribute to a neuroprotective effect. ${ }^{67}$ The neuroprotective role of $\alpha 7$ nAChRs in the retina was therefore explored.

Neuronal nAChRs represent a very heterogeneous family of ion channels. In the nervous system, nine different alpha subunits $(\alpha 2-\alpha 10)$ and three different beta subunits $(\beta 2-\beta 4)$ have been described. ${ }^{28,81,82}$ These subunits assemble in vivo to form various combinations, although $\alpha 7$ subunits form homo-pentamers in heterologous expression systems. In the brain, $\alpha 7$, $\alpha 4$, and $\beta 2$ are the most abundant nAChRs, and there is growing evidence for $\alpha 7$ in the retina. ${ }^{83,84}$ Initial pharmacological studies supported the hypothesis that $\alpha$-Bgt-sensitive $\alpha 7$ nAChR subunits were responsible for the neuroprotective effect of ACh; relatively low concentrations of $\alpha$-Bgt inhibited the effect of ACh. However, because much of the commercially available $\alpha$-Bgt contains small amounts of contaminants that can affect other nAChR subunits, further pharmacological experiments were performed using the $\alpha 7$ agonist, choline, and the $\alpha 7$ antagonist, MLA, to address this issue. Results demonstrated that although choline had a significant neuroprotective effect on RGCs, it only represented approximately one-half of the protective effect observed when cells were pretreated with $5 \mu \mathrm{M}$ ACh. In inhibition studies, low concentrations of MLA that are specific for $\alpha 7 \mathrm{nAChR}$ subunits completely blocked the neuroprotective effect of choline. These results strongly suggested that $\alpha 7 \mathrm{nAChR}$ subunits were involved in ACh neuroprotection, but additional nAChR subunits were also involved. Further experiments are needed to identify and characterize the contribution of these other putative nAChR subunits.

How can activation of nAChR subunits lead to neuroprotection? Although the answer to this question is outside the scope of this article, it is likely that activation of nAChRs triggers a cascade of events ultimately inhibiting apoptotic pathways or enhancing cell survival pathways. The catalyst for triggering these cascades could be due to changes of membrane potential that occur when nAChR channels open, but more likely is due to ion permeation through activated nAChR channels. Nicotinic AChRs are nonspecific cation channels highly permeable to calcium ions. ${ }^{60,85,86}$ Calcium ions have been shown to affect a wide variety of intracellular second messenger cascades, including the MAP kinase pathways and PI3 kinase pathways, ${ }^{67,87}$ which are involved in ACh neuroprotection in other regions of the CNS. It is therefore likely that calcium permeation through calcium-permeable nAChRs triggers inhibition or activation of second messenger systems to inhibit apoptosis or enhance cell survival. In this scenario, high calcium influx through glutamate channels are excitotoxic, whereas calcium influx through nACh channels results in neuroprotection. How can calcium influx trigger two separate actions in the same cell? Perhaps the answer is due to cell compartmentalization that separates calcium-sensitive neuroprotective enzymes from calcium sensitive enzymes involved in excitotoxicity, or perhaps the amount of calcium influx through channels is the key. For instance, it is conceivable that a narrow range of calcium results in protection rather than excitotoxicity. Certainly, further experiments are needed to test these ideas.

In summary, this study was the first to demonstrate the isolation of adult pig retinal ganglion cells using a modified two-step panning technique using Thy1.1 antibody. That chronic exposure of $500 \mu \mathrm{M}$ L-glutamate induced excitotoxicity in cultured adult pig RGCs through a combination of both
NMDA and non-NMDA GluRs was also determined. In addition, this study was first to demonstrate that an endogenous neurotransmitter found in the retina, $\mathrm{ACh}$, has a neuroprotective effect against glutamate-induced neurotoxicity of RGCs and that ACh acts through $\alpha$-Bgt-sensitive nAChRs, with involvement of $\alpha 7$ nAChRs. These findings suggest that ACh may be useful in protecting RGC from excitotoxic and traumatic insults similar to those occurring in glaucoma. A better understanding of this neuroprotective pathway may lead to therapeutic intervention for glaucoma and a variety of other neuronal diseases in the retina and other regions of the CNS.

\section{Acknowledgments}

The authors thank John Spitsbergen for helpful information concerning culturing techniques; Christine Byrd, John Jellies, and William Jackson for helpful comments concerning the manuscript; and Rob Eversole for fluorescence microscopy expertise.

\section{References}

1. Choi DW. Glutamate neurotoxicity and disease of the nervous system. Neuron. 1988;1:623-634.

2. Romano $\mathrm{C}$, Chen $\mathrm{Q}$, Olney JW. The intact (ex vivo) retina as a model system for the study of excitotoxicity. Prog Ret Eye Res. 1998; $17: 465-483$

3. Quigley HA. Neuronal death in glaucoma. Prog Ret Eye Res. 1998; 18:39-57.

4. Lafuente MP, Villegas-Perez PM, Sobrado-Calvo P, Garcia-Aviles A, Miralles de Imperial J, Vidal-Sanz M. Neuroprotective effects of alpha (2)-selective adrenergic agonists against ischemia-induced retinal ganglion cell death. Invest Opbthalmol Vis Sci. 2001;42: 2074-2084.

5. Vickers BM, Schumer RA, Podos SM, Wang RF, Riederer BM, Morrison JH. Differential vulnerability of neurochemically identified subpopulations of retinal neurons in a monkey model of glaucoma. Brain Res. 1995;680:23-35.

6. Brooks DE, Garcia GA, Dreyer EB, Zurakowski D, Franco-Bourland RE. Vitreous body glutamate concentration in dogs with glaucoma. Amer J Vis Res. 1997;58:864-867.

7. Dkhissi O, Chanut E, Wasowicz M, et al. Retinal TUNEL-positive cells and high glutamate levels in vitreous humor of mutant quail with a glaucoma-like disorder. Invest Opbthalmol Vis Sci. 1999; 40:990-995.

8. Quigley HA, Nickells RW, Kerrigan LA, Pease ME, Thibault DJ, Zack DJ. Retinal ganglion cell death in experimental glaucoma and after axotomy occurs by apoptosis. Invest Ophthalmol Vis Sci. 1995;36:774-786.

9. Lam TT, Abler AS, Kwong JMK, Tso MOM. N-methyl-D-aspartate (NMDA)-induced apoptosis in rat retina. Invest Ophthalmol Vis Sci. 1999;40:2391-2397.

10. Hamassaki-Britto DE, Hermans-Borgmeyer I, Heinemann S, Hughes TE. Expression of glutamate receptor genes in the mammalian retina: the localization of GluR1 through GluR7 mRNAs. J Neurosci. 1993;13:1888-1898.

11. Watanabe $M$, Mishina $M$, Inoue $Y$. Distinct spatiotemporal distributions of the N-methyl-D-aspartate receptor channel subunit mRNAs in the mouse cervical cord. J Comp Neurol. 1994;345: 314-319.

12. Goebel DJ, Aurelia JL, Tai Q, Jojich L, Poosch MS. Immunocytochemical localization of the NMDA-R2A receptor subunit in the cat retina. Brain Res. 1998;808:141-154.

13. Lin B, Martin PR, Grunert U. Expression and distribution of ionotropic glutamate receptor subunits on parasol ganglion cells in the primate retina. Vis Neurosci. 2002;4:453-465.

14. Glovinsky Y, Quigley HA, Dunkelberger GR. Retinal ganglion cell loss is size dependent in experimental glaucoma. Invest Ophthalmol Vis Sci. 1991;32:484-491.

15. Dreyer EB, Pan Z-H, Storm S, Lipton SA. Greater sensitivity of larger retinal ganglion cells to NMDA-mediated cell death. NeuroReport. 1994;5:629-631. 
16. Hahn JS, Aizenman E, Lipton SA. Central mammalian neurons normally resistant to glutamate toxicity are made sensitive by elevated extracellular calcium: toxicity is blocked by the N-methylD-aspartate antagonists MK-801. Proc Nat Acad Sci. 1988;85: 6556-6560.

17. Kitano S, Morgan J, Caprioli J. Hypoxic and excitototoxic damage to cultured rat retinal ganglion cells. Exp Eye Res. 1996;63:105112.

18. Mosinger JL, Prince MT, Bai HY, Xiao H, Wozniak DF, Olney JW. Blockade of both NMDA and non-NMDA receptors is required for optimal protection against ischemic neuronal degeneration in the in vivo adult mammalian retina. Exp Neurol. 1991;113:10-17.

19. Otori Y, Wei JY, Barnstable CJ. Neurotoxic effects of low doses of glutamate on purified rat retinal ganglion cells. Invest Ophthalmol Vis Sci. 1998;39:972-981.

20. Marin P. Maus M, Desagher S, Glowinski J, Premont J. Nicotine protects cultured striatal neurones against N-methyl-D-aspartate receptor-mediated neurotoxicity. Neuroreport. 1994;5:18511855.

21. Shimohama S, Akaike A, Kimura J. Nicotine-induced protection against glutamate cytotoxicity. Nicotinic cholinergic receptor-mediated inhibition of nitric oxide formation. Ann NY Acad Sci. 1996;17:356-361.

22. Kaneko S, Maeda T, Kume $\mathrm{T}$, et al. Nicotine protects cultured cortical neurons against glutamate-induced cytotoxicity via alpha7neuronal receptors and neuronal CNS receptors. Brain Res. 1997; 765:135-140.

23. Dajas-Bailador FA, Lima PA, Wonnacott $S$. The a-7 nicotinic receptor subtype mediates nicotine protection against NMDA excitotoxicity in primary hippocampal cultures through a $\mathrm{Ca}^{2+}$ dependent mechanism. Neuropharm. 2000;39:2799-2807.

24. Famiglietti EV Jr. Starburst amacrine cells and cholinergic neurons: mirror-symmetric on and off amacrine cells of rabbit retina. Brain Res. 1983;261:138-144.

25. Masland RH, Mills JW, Hayden SA. Acetylcholine-synthesizing amacrine cells: identification and selective staining by using radioautography and fluorescent markers. Proc $R$ Soc Lond B Biol Sci. 1984;223:79-100.

26. Mariani AP, Hersh LB. Synaptic organization of cholinergic amacrine cells in the rhesus monkey retina. J Comp Neurol. 1988;267: 269-280.

27. Keyser KT, Hughes TE, Whiting PJ, Lindstrom JM, Karten HJ. Cholinoceptive neurons in the retina of the chick: an immunohistochemical study of the nicotinic acetylcholine receptors. Vis Neurosci. 1988;1:349-366.

28. Whiting PJ, Schoepfer R, Conroy WG, et al. Expression of nicotinic acetylcholine receptor subtypes in brain and retina. Mol Brain Res. 1991;10:61-70.

29. Keyser KT, Britto LGR, Schoepfer R, et al. Three subtypes of a-Bgt-sensitive nicotinic Ach receptors are expressed in chick retina. J Neurosci. 1993;13:442-454.

30. Kaneda M, Hashimoto M, Kaneko A. Neuronal nicotinic acetylcholine receptors of ganglion cells in the cat retina. Jpn J Physiol. 1995;45:491-508.

31. Reed BT, Amthor FR, Keyser KT. Rabbit retinal ganglion cell responses mediated by alpha-bungarotoxin-sensitive nicotinic acetylcholine receptors. Vis Neurosci. 2002;19:427-438.

32. Guenther E, Schmid S, Grantyn R, Zrenner E. In vitro identification of retinal ganglion cells in culture without the need of dye labeling. J Neurosci metbods. 1994;51:177-181.

33. Barres BA, Silverstein BE, Corey DP, Chun LLY. Immunological, morphological and electrophysiological variation among retinal ganglion cells purified by panning. Neuron. 1988;1:791-803.

34. Bozyczko-Coyne D, McKenna BW, Connors TJ, Neff NT. A rapid fluorometric assay to measure neuronal survival in vitro. J Neurosci Methods. 1993;50:205-216.

35. Barnstable CJ, Drager UC. Thy-1 antigen: a ganglion cell specific marker in rodent retina. Neurosci. 1984;11:847-855.

36. Kawasaki A, Han MH, Wei JY, Hirata K, Otori Y, Barnstable CJ. Protective effect of arachidonic acid on glutamate neurotoxicity in rat retinal ganglion cells. Invest Opbthalmol Vis Sci. 2002;43: 1835-1842.
37. Luo X, Heidinger V, Picaud S, et al. Selective excitotoxic degeneration of adult pig retinal ganglion cells in vitro. Invest Ophthalmol Vis Sci. 2001;42:1096-1106.

38. Britto LR, Rogers SW, Hamassaki-Britto DE, Duvoisin RM. Nicotinic acetylcholine receptors in the ground squirrel retina: localization of the beta 4 subunit by immunohistochemistry and in situ hybridization. Vis Neurosci. 1994;11:569-577.

39. Araki CM, Pires RS, Britto LR, Lindstrom JM, Karten HJ, HamassakiBritto DE. Differential co-localization of nicotinic acetylcholine receptor subunits with calcium-binding proteins in retinal ganglion cells. Brain Res. 1997;774:250-255.

40. Chen D, Patrick JW. The alpha-bungarotoxin-binding nicotinic acetylcholine receptor from rat brain contains only the alpha7 subunit. J Biol Chem. 1997;272:24024-24029.

41. Jonnala RR, Graham JH III, Terry AV Jr, Beach JW, Young JA, Buccafusco JJ. Relative levels of cytoprotection produced by analogs of choline and the role of alpha7-nicotinic acetylcholine receptors. Synapse. 2003;47:262-269.

42. Alkondon M, Pereira EFR, Wonnacott S, Albuquerque EX. Blockade of nicotinic currents in hippocampal neurons defines methyllycaconitine as a potent and specific receptor antagonist. Mol Pharmacol. 1992; 4:802-808.

43. Klink R, deKerchove d'Exaerde A, Zoli M, Changeux J-P. Molecular and physiological diversity of nicotinic ACh receptors in the midbrain dopaminergic nuclei. J. Neurosci. 2001;21:1452-1463.

44. Yum L, Wolf KM, Chiappinelli VA. Nicotinic acetylcholine receptors in separate brain regions exhibit different affinities for methyllycaconitine. Neurosci. 1996;72:545-555.

45. Zoli M, Moretti M, Zanardi A, McIntosh JM, Clementi F, Gotti C. Identification of the nicotinic receptor subtypes expressed on dopaminergic terminals in the rat striatum. $J$ Neurosci. 2002;22; 8785-8789.

46. Vailati S, Moretti M, Longhi R, Rovati GE, Clementi F, Gotti C. Developmental expression of heteromeric nicotinic receptor subtypes in chick retina. Mol Pharmacol. 2003;63:1329-1337.

47. Papke RL, Bencherif M, Lippiello P. An evaluation of neuronal nicotinic acetylcholine receptor activation by quaternary nitrogen compounds indicates that choline is selective for the alpha 7 subtype. Neurosci Lett. 1996;213:201-204.

48. Papke RL, Porter Papke JK. Comparative pharmacology of rat and human alpha $7 \mathrm{nAChR}$ conducted with net charge analysis. $\mathrm{BrJ}$ Pharmacol. 2002;137:49-61.

49. Alkondon M, Pereira EF, Cortes WS, Maelicke A, Albuquerque EX. Choline is a selective agonist of alpha7 nicotinic acetylcholine receptors in the rat brain neurons. Eur J Neurosci. 1997;9:27342742 .

50. Zwart R, Vijverberg HP. Potentiation and inhibition of neuronal alpha4beta4 nicotinic acetylcholine by choline. Eur J Pharmacol. 393:209-214, 2000

51. Sinclair CM, Bartlett PF, Greig DI, Jeffrey PL. Distribution of Thy-1 in the avian nervous system: immunohistochemical and absorption analyses with monoclonal antibody. Brain Res. 1986;398:91-105.

52. Saleh M, Bartlett PF. Isolation of a Thy-1-like glycoprotein from cat brain: distribution in retina and brain defined by monoclonal antibodies. J Neurosci Res. 1989;23:152-161.

53. Vaughan DK, Erickson PA, Fisher SK. Glial fibrillary acidic protein (GFAP) immunoreactivity in rabbit retina: effect of fixation. Exp Eye Res. 1990;50:385-392.

54. Wygnanski T, Desatnik H, Quigley HA, Glovinsky Y. Comparison of ganglion cell loss and cone loss in experimental glaucoma. AmJ Ophthalmol. 1995;120:184-189.

55. Linn DM, Massey SC. Acetylcholine release from the rabbit retina mediated by NMDA receptors. J Neurosci. 1991;11:123-133.

56. Muller F, Greferath U, Wassle H, Wisden W, Seeburg P. Glutamate receptor expression in the rat retina. Neurosci Lett. 1992;138: 179-182.

57. Brandstatter JH, Hartveit E, Sassoe-Pognetto M, Wassle H. Expression of NMDA and high-affinity kainate receptor subunit mRNAs in the adult rat retina. Eur J Neurosci. 1994;6:1100-1112.

58. Koh DS, Geiger JRP, Jonas P, Sakmann B. Calcium permeable AMPA and NMDA receptor channels in basket cells of rat hippocampal dentate gyrus. J Physiol. 1995;485:383-402. 
59. Otis TS, Raman IM, Trussell LO. AMPA receptors with high calcium permeability mediate synaptic transmission in the avian auditory pathway. J Physiol. 1995;482:309-315.

60. Burnashev N. Calcium permeability of ligand-gated channels. Cell Calcium. 1998;24:325-332.

61. Budd SL, Tenneti L, Lishnak T, Lipton SA. Mitochondrial and extramitochondrial apoptotic signaling pathways in cerebrocortical neurons. Proc Natl Acad Sci USA. 2000;97:6161-6166.

62. Lipton SA, Choi YB, Pan ZH, et al. A redox-based mechanism for the neuroprotective and neurodestructive effects of nitric oxide and related nitroso-compounds. Nature. 1993;364:626-632.

63. Bonfoco E, Krainc D, Ankarcrona M, Nicotera P, Lipton SA. Apoptosis and necrosis: two distinct events induced, respectively, by mild and intense insults with N-methyl-D-aspartate or nitric oxide/superoxide in cortical cell cultures. Proc Natl Acad Sci USA. 1995;92:7162-7166.

64. Leifer D, Krainc D, Yu YT, et al. MEF2C, a MADS/MEF2-family transcription factor expressed in a laminar distribution in cerebral cortex. Proc Natl Acad Sci USA. 1993;90:1546-1550.

65. Okamoto S, Krainc D, Sherman K, Lipton SA. Antiapoptotic role of the p38 mitogen-activated protein kinase-myocyte enhancer factor 2 transcription factor pathway during neuronal differentiation. Proc Natl Acad Sci USA. 2000;97:7561-7566.

66. Pavlovic D, Andersen N, Mandrup-Poulsen T, Zizirik DL. Activation of extracellular signal-regulated kinase (ERK)1/2 contributes to cytokine-induced apoptosis in purified rat pancreatic b-cells. Eur Cytokine Network. 2000;11:267-274.

67. Shaw S, Bencherif M, Marrero MB. Janus kinase 2, an early target of alpha7 nicotinic acetylcholine receptor-mediated neuroprotection against A $\beta-(1-42)$ amyloid. J Biol Chem. 2002;277:44920-44924.

68. Tenneti L, D'Emilia DM, Troy CM, Lipton SA. Role of caspases in $\mathrm{N}$-methyl-D-aspartate-induced apoptosis in cerebrocortical neurons. J Neurochem. 1998;71:946-959.

69. Wein FB, LA Levin. Current understanding of neuroprotection in glaucoma. Curr Opin Ophthalmol. 2002;13:61-67.

70. Ahmed FA, Hegazy K, Chaudhary P, Sharma SC. Neuroprotective effect of alpha (2) agonist (brimonidine) on adult rat retinal ganglion cells after increased intraocular pressure. Brain Res. 2001; 913:133-139.

71. Wood JP, DeSantis L, Chao HM, Osborne NN. Topically applied betaxolol attenuates ischemia-induced effects to rat retina and stimulates BDNF mRNA. Exp Eye Res. 2001;72:79-86.

72. Chen $\mathrm{H}$, Weber AJ. BDNF enhances retinal ganglion cell survival in cats with optic nerve damage. Invest Ophthalmol Vis Sci. 2001; 42:966-974.

73. Saitoh T, Mishima HK, Shoge K, Ishihara K, Sasa M. Protection against glutamate neurotoxicity in retinal cultures by acidic conditions. Jpn J Pharmacol. 1998;76:87-95.
74. Broide RS, Leslie FM. The alpha7 nicotinic acetylcholine receptor in neuronal plasticity. Mol Neurobiol. 1999;20:1-16.

75. Tanaka H, Calderone A, Jover $\mathrm{T}$, et al. Ischemic preconditioning acts upstream of GluR2 down-regulation to afford neuroprotection in the hippocampal CA1. Proc Natl Acad Sci USA. 2002;99:23622367.

76. Kipnis J, Yoles E, Schori H, Hauben E, Shaked I, Schwartz M. Neuronal survival after CNS insult is determined by a genetically encoded autoimmune response. J Neurosci. 2001;21:4564-4571.

77. Kopf M, Baumann H, Freer G, et al. Impaired immune and acutephase responses in interleukin-6-deficient mice. Nature. 1994;368: 339-342.

78. Schwartz M. Neurodegeneration and neuroprotection in glaucoma: development of a therapeutic neuroprotective vaccine. Invest Ophthal Vis Sci. 2003;44:1407-1411.

79. Donnelly-Roberts DL, Xue IC, Arneric SP, Sullivan JP. In vitro neuroprotective properties of the novel cholinergic channel activator (ChCA), ABT-418. Brain Res. 1996;719:36-44.

80. Kihara T, Shimohama S, Sawada H, et al. Alpha 7 nicotinic receptor transduces signals to phosphatidylinositol 3-kinase to block betaamyloid-induced neurotoxicity. J Biol Chem. 2001;276:1354113546.

81. Seguela P, Wadiche J, Dineley-Miller K, Dani JA, Patrick JW. Molecular cloning, functional properties and distribution of rat brain alpha7: a nicotinic cation channel highly permeable to calcium. J Neurosci. 1993;13:596-604.

82. Sargent $\mathrm{PB}$. The diversity of neuronal nicotinic acetylcholine receptor. Ann Rev Neurosci. 1993;16:403-443.

83. Linn DM, Cortes-Borgos L, McFinton P, et al. Characterization and expression of nicotinic ACh receptors in the mammalian retina. Invest Ophthalmol Vis Sci Abst. 2002;43:731.

84. Reed BT, Strang CE, Brockway LM, Amthor FR, Keyser KT. MLA Sensitivity in the rabbit retina is mediated by functional alpha7 nAChRS. Invest Opbthalmol Vis Sci Abst. 2002;43:4770.

85. Rogers M, Dani JA. Comparison of quantitative calcium flux through NMDA, ATP and ACh receptor channels. Biopbys J. 1995; 68:501-506.

86. Ragozzino D, Barabino B, Fucile S, Eusebi F. Calcium permeability of mouse and chick nicotinic acetylcholine receptors expressed in transiently transfected human cells. J Physiol. 1998;507:749-757.

87. Dineley KT, Westerman M, Bui D, Bell K, Ashe KH, Sweatt JD. Beta-amyloid activates the mitogen-activated protein kinase cascade via hippocampal alpha7 nicotinic acetylcholine receptors: in vitro and in vivo mechanisms related to Alzheimer's disease. J Neurosci. 2001;21:4125-4133. 